\title{
EFEKTIVITAS PERAWATAN MANDIRI DIBANDINGKAN KUNJUNGAN RUMAH TERHADAP KEPERCAYAAN DIRI IBU MENYUSUI
}

\section{THE EFFECTIVITY OF HOME VISIT AND SELF-CARE TREATMENT METHODS ON SELF-EFFICACY OF BREASTFEEDING MOTHERS}

\author{
Ernani Setyawati ${ }^{1 *}$ \\ ${ }^{* 1}$ Politeknik Kesehatan Kemenkes Kalimantan Timur Prodi DIII Kebidanan Balikpapan, Jalan Sorong RT 81 \\ No 9 Gatu Kelurahan Muara Rapak Balikpapan, Email: esetyawati80@gmail.com, Indonesia
}

\begin{abstract}
Background:Breastfeeding is not always easy. Mother should have high confidence to breastfeed the infant to get positive response in facing difficulties of breastfeeding.

Objective: The purpose of this study was to compare the methods of self-care and home visit as the efforts to increase mothers' brestfeeding self- efficacy.

Methods: A comparative analytical study using quasy experimental design including 23 subject selected in the home visit group and 23 subjects in the self-care group by using consecutive sampling technique was taken place in two hospital at Balikpapan, Indonesia. The data were then analyzed by using Wilcoxon and Mann Whitney test.

Results: The results showed that mothers' breastfeeding self-efficacy score before treatment in both groups $(\bar{x}$ self care $=65.52 ; \bar{x}$ home visit $=63.65)$ while self-efficacy score after treatment in both groups $(\bar{x}$ self care $=73.39 ; \bar{x}$ home visit $=74.91)$. The self-efficacy score in self care groups before and after treatment $(Z W$ $=5.317, p>.05)$ in home visit groups were $Z w=3.564$ ( $p>.05)$. Mothers' breastfeeding self-efficacy score in home visit and self care groups before treatment was $Z_{M W}=.231(p>.05)$. as compared to self-efficacy score in home visit and self care groups after treatment was $Z_{M W}=.793(p>.05)$

Conclusion: The study showed that home visit method and self-care method are equally good in increasing mothers' self-efficacy.
\end{abstract}

Keywords: breastfeeding, home visit, self-efficacy, self care.

\section{PENDAHULUAN}

Pemberian air susu ibu pada bayi baru lahir telah terbukti merupakan makanan terbaik bagi bayi baru lahir karena sesuai dengan kebutuhan dan pencernaan bayi untuk mencapai pertumbuhan dan perkembangan yang maksimal. Keberhasilan menyusui pada bayi dapat dipengaruhi oleh faktor bayi dan faktor ibu. Faktor bayi dipengaruhi oleh perkembangan fungsi oralmotor yang sangat tergantung pada usia kehamilannya. Semakin muda usia kehamilan pada saat bayi dilahirkan maka bayi akan semakin sulit menyusu pada ibu. ${ }^{1}$
Faktor yang lebih penting adalah faktor psikologis ibu yang dapat menyebabkan seorang ibu tidak mau menyusui bayinya walaupun tidak mengalami gangguan pada payudaranya. Faktor psikologis dapat memengaruhi proses produksi $\mathrm{ASI} /$ refleks prolaktin dan refleks pengeluaran $\mathrm{ASI} /$ refleks oksitosin, sehingga produksi ASI tidak maksimal atau ibu merasa produksi ASI-nya tidak maksimal. Keadaan psikologis yang sangat berperan adalah kesedihan, ketakutan, kurangnya kepercayaan diri, dan kurangnya dukungan untuk menyusui. ${ }^{1}$ 
Kepercayaan diri seorang ibu dalam menyusui merupakan komponen yang penting untuk menjamin keberlangsungan proses menyusui. Teori ini dikembangkan berdasarkan teori perilaku sosial kognitif Bandura. Kepercayaan diri ibu menyusui yang ditunjukkan dengan efikasi diri merupakan keyakinan diri yang dimiliki seorang ibu terhadap kemampuannya untuk menyusui bayinya yang akan berpengaruh terhadap usaha, perhatian terhadap proses menyusui, dan responnya terhadap masalah menyusui yang dialami. lbu yang kepercayaan dirinya tinggi dalam menyusui akan berusaha mengatasi dan mempertahankan kegiatan menyusui. Dengan demikian, keberlangsungan proses menyusui akan lebih tinggi pada ibu dengan

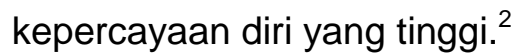

Penelitian sebelumnya menunjukkan hasil yang positif untuk membantu ibu menyusui melalui dukungan keluarga terutama suami, dukungan dari tenaga kesehatan, dan dukungan dari teman sebaya. Dukungan tenaga kesehatan melalui kunjungan rumah dipercaya mampu mendukung kesuksesan ibu menyusui pada bayi cukup bulan dibandingkan ibu yang hanya mendapat perawatan di rumah sakit. Sedangkan perawatan mandiri menyusui memberikan alternatif promosi kesehatan untuk peningkatan kepercayaan diri ibu menyusui pada bayi dengan usia kehamilan rata-rata 39 minggu. ${ }^{3}$
Peningkatan pengetahuan mengenai pentingnya $\mathrm{ASI}$ bagi bayi melalui kegiatan penyuluhan di pelayanan kesehatan belum mampu meningkatkan angka keberlangsungan ibu menyusui di Indonesia, ditunjukkan dengan masih rendahnya angka sebesar 56,4\% untuk pemberian ASI eksklusif. ${ }^{4}$

Peningkatan pengetahuan dan kepercayaan diri ibu menyusui sebagai salah satu cara untuk meningkatkan kemampuan ibu menyusui bayinya perlu didukung oleh semua pihak, sehingga dapat menjamin keberhasilan pemberian ASI eksklusif

Balikpapan merupakan salah satu kota di provinsi Kalimantan Timur dengan cakupan ASI eksklusif secara keseluruhan tahun 2012 baru mencapai $60,44 \%$, masih di bawah target nasional yaitu $70 \%$. Faktor yang menjadi penyebabnya adalah perilaku menyusui yang kurang mendukung, pemberian makan/minuman sebelum ASI keluar, kurangnya rasa percaya diri ibu bahwa ASI cukup untuk bayinya, ibu kembali bekerja setelah cuti bersalin, kurangnya dukungan menyusui dari kantor dan kurangnya sarana/fasilitas menyusui, serta gencarnya promosi susu formula. ${ }^{5}$

Penelitian ini bertujuan membandingkan efektifitas metode perawatan mandiri dengan kunjungan rumah terhadap peningkatan kepercayaan diri lbu Menyusui.M. Penelitian ini akan bermanfaat untuk mendapatkan metode perawatan terbaik untuk meningkatkan kepercayaan diri 
ibu menyusui sehingga dapat menjamin keberlangsungan menyusui.

\section{BAHAN DAN CARA PENELITIAN}

Desain penelitian adalah quasi experimental. Sampel penelitian diambil secara purposive sampling di RSUD dr. Kanujoso Djatiwibowo dan RSUD Gunung Malang di kota Balikpapan pada bulan Oktober - Desember 2016 dengan jumlah sampel 23 ibu menyusui untuk kelompok kunjungan rumah, dan 23 ibu menyusui untuk kelompok perawatan mandiri. Penelitian ini telah mendapatkan persetujuan dari Komisi Etik Penelitian Universitas Muhammadiyah Banjarmasin Nomor: 365/UMB/KE/XII/2016.

Variabel bebas dalam penelitian ini adalah metode perawatan kunjungan rumah dan mandiri, sedangkan variabel terikat adalah kepercayaan diri lbu menyusui. Kriteria inklusi penelitian adalah ibu nifas sehat yang melahirkan bayi $>2.500 \mathrm{gr}$, usia kehamilan di atas 37 minggu, dan dirawat di rumah sakit yang menjadi tempat penelitian. Sedangkan kriteria eksklusi dalam penelitian ini adalah ibu menderita sakit dan tidak dianjurkan menyusui, bayi sakit berat, terdapat kelainan kongenital, ibu tidak dapat melihat dan membaca.

Objek pada kelompok kunjungan rumah mendapatkan perawatan menyusui sesuai standar di rumah sakit tempat ibu dirawat, kemudian setelah dipulangkan objek penelitian mendapatkan kunjungan rumah sebanyak 1 kali dari tenaga kesehatan. Pada saat kunjungan rumah, subjek penelitian mendapatkan perawatan standar kunjungan rumah. Sedangkan kelompok mandiri mendapatkan pendidikan kesehatan berupa panduan dan video menyusui selama dirawat, dan setelah dipulangkan objek diberikan panduan dan video untuk dipelajari di rumah. Panduan dan video menyusui disusun berdasarkan panduan Sentra Laktasi Indonesia. ${ }^{6}$

Pengambilan data skor kepercayaan diri dilakukan sebelum objek mendapatkan perawatan, sedangkan evaluasi dilakukan satu minggu masa nifas. Penilaian kepercayaan ibu menyusui menggunakan kuesioner kepercayaan diri lbu menyusui dari Denis berupa skala likert. ${ }^{2}$ Analisis data menggunakan uji Wilcoxon dan Mann Whitney.

\section{HASIL DAN PEMBAHASAN}

Tabel 1 Perbandingan Skor Kepercayaan Diri pada Kedua Kelompok Perlakuan $(\mathrm{N}=46)$

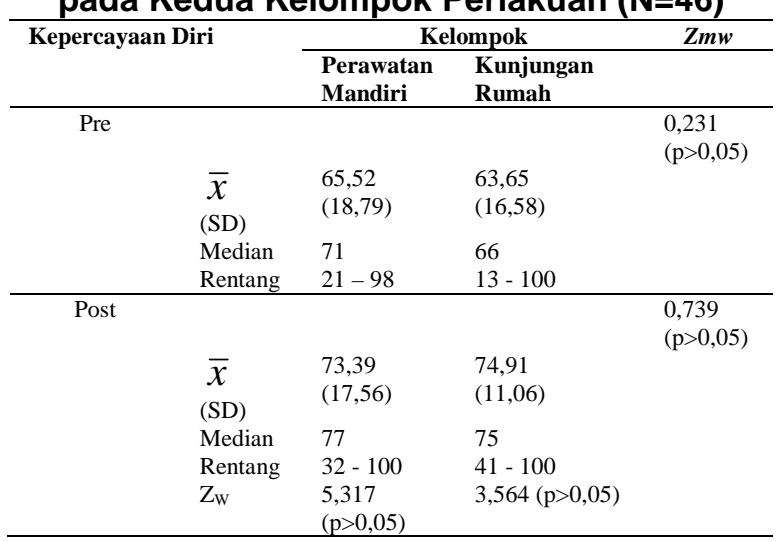

Sumber: Data primer 2016

Sebagian besar Ibu menyusui berusia 20-35 tahun, multipara, dengan tingkat pendidikan sekolah dasar pada kedua 
kelompok. Skor rata-rata kepercayaan diri ibu menyusui sebelum dan sesudah perlakuan pada kedua kelompok penelitian dapat dilihat pada tabel 1 .

Dari tabel 1 terlihat bahwa skor ratarata kepercayaan diri kelompok mandiri sebelum dan setelah perlakuan cenderung lebih tinggi dibandingkan kelompok kunjungan rumah.

Peningkatan perubahan skor kepercayaan diri sebelum dan setelah perlakuan pada kedua kelompok penelitian dapat diperlihatkan secara lebih jelas melalui gambar 1.

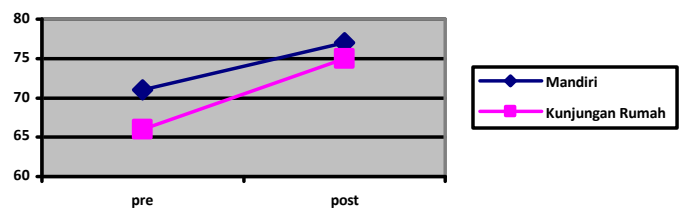

Gambar 1 Grafik Peningkatan Kepercayaan Diri Sebelum dan Setelah Perlakuan pada Kelompok Perawatan Mandiri dan Kunjungan Rumah

Dari gambar 1 terlihat bahwa meskipun tidak ada perbedaan perubahan skor kepercayaan diri yang signifikan pada kedua kelompok, tetapi perawatan mandiri memiliki kecenderungan yang lebih baik dalam meningkatkan skor kepercayaan diri ibu menyusui.

Pada awal penelitian, tingkat kepercayaan diri objek pada kelompok perawatan mandiri lebih tinggi dibandingkan kepercayaan diri objek kelompok perawatan kunjungan rumah. Hasil akhir penelitian juga menunjukkan kepercayaan diri ibu menyusui kelompok perawatan mandiri lebih tinggi dibandingkan kelompok perawatan kunjungan rumah. Kecenderungan peningkatan lebih tinggi pada perawatan mandiri mengindikasikan bahwa ibu menyusui BBL dapat dilibatkan secara aktif dalam pemenuhan kebutuhan nutrisi BBL, termasuk mengatasi masalah dalam menyusui dan memepertahankan asi eksklusif.

Metode perawatan baik yang bersifat individu maupun komunitas dapat meningkatkan kepercayaan diri ibu menyusui, sehingga pengembangan dan kombinasi berbagai metode perawatan perlu dilakukan untuk mendapatkan metode perawatan yang efektif dalam upaya peningkatan kepercayaan diri ibu menyusui.

$$
\text { Hasil analisis perbandingan }
$$
kepercayaan diri ibu menyusui sebelum dan setelah perlakuan pada metode perawatan kunjungan rumah menunjukkan peningkatan yang bermakna, menunjukkan pengaruh dukungan dari tenaga kesehatan. ${ }^{7}$

Pengaruh tenaga kesehatan dalam perawatan kunjungan rumah disebabkan objek mendapatkan edukasi secara individu dan pendekatan persuasif. Dukungan positif dari tenaga kesehatan menjadi sumber informasi yang dapat meningkatkan kepercayaan diri ibu serta mengurangi rasa stres yang dialami oleh ibu. Peningkatan kepercayaan diri dengan metode perawatan kunjungan rumah sesuai dengan teori Dennis yang mengemukakan kepercayaan diri ibu 
menyusui dapat dipengaruhi oleh pendekatan persuasif dan bantuan mengatasi masalah psikologis masa nifas yang dilakukan oleh tenaga kesehatan. ${ }^{2}$

Hasil analisis perbandingan kepercayaan diri ibu menyusui sebelum dan setelah perlakuan pada metode perawatan mandiri juga menunjukkan peningkatan yang bermakna. Peningkatan kepercayaan diri ibu menyusui dengan metode perawatan mandiri ini sesuai dengan penelitian Awano dkk. di Jepang, meskipun dengan karakteristik objek penelitian yang berbeda. Awano dkk. melakukan evaluasi program perawatan mandiri menggunakan panduan dan cheklist keterampilan menyusui, serta video mengenai menyusui yang diberikan pada ibu. Evaluasi kepercayaan diri ibu menyusui dilakukan pada hari keempat dan satu bulan masa nifas. Metode ini terbukti efektif meningkatkan kepercayaan diri ibu menyusui dengan bayi lahir normal di Jepang. ${ }^{8}$

Metode perawatan mandiri telah membuktikan teori Bandura yang menyatakan sumber informasi dapat meningkatkan kepercayaan diri seorang ibu menyusui, yaitu melalui pengalaman pengganti dengan memberikan pengetahuan keterampilan menyusui kepada ibu serta antisipasi masalah yang mungkin muncul selama proses menyusui. ${ }^{7}$

Hasil penelitian juga memperkuat teori individu memiliki kemampuan untuk terlibat dalam perawatan diri, tergantung pada perkembangan usia, pengalaman hidup, orientasi sosial kultural, dan sumber daya yang tersedia. ${ }^{7}$ lbu dapat dilibatkan dalam proses pembelajaran menyusui secara aktif dan disesuaikan dengan kemampuan ibu menyesuaikan diri pada kegiatan menyusui. Perawatan mandiri memungkinkan seorang ibu mempelajari cara menyusui melalui media cetak dan audio visual. Leaflet dan video yang diberikan pada ibu telah sesuai dengan panduan menyusui, serta dapat dibaca atau dilihat berulang kali oleh objek penelitian secara mandiri.

Keterbatasan penelitian ini adalah belum melibatkan faktor lain yang dapat memengaruhi kepercayaan diri ibu menyusui seperti faktor budaya dan dukungan dari keluarga dalam upaya meningkatkan kepercayaan diri ibu menyusui.

\section{KESIMPULAN}

Pengaruh metode perawatan mandiri dan kunjungan rumah sama baiknya dalam upaya meningkatkan kepercayaan diri ibu menyusui. Penelitian lebih lanjut pada upaya peningkatan kepercayaan diri ibu menyusui dapat dikembangkan dengan meneliti faktor lain seperti budaya dan dukungan dari keluarga. Bagi rumah sakit dan bidan praktik disarankan untuk menggabungkan kedua metode perawatan untuk meningkatkan kepercayaan diri ibu menyusui.

\section{TERIMAKASIH}

1. Kepala Badan PPSDM Kementerian Kesehatan Republik Indonesia 
2. Drs. H. Lamri, M.Kes, Direktur Poltekkes Kemenkes Kalimantan Timur.

3. DR. Endah Wahyutri, M.Kep, Ketua Unit PPM Poltekkes Kemenkes Kalimantan Timur.

\section{KEPUSTAKAAN}

1. Suradi R, Hegar B, Partiwi IGAN, Marzuki ANS, Ananta Y. Indonesia menyusui. Badan Penerbit IDAI; 2010.

2. McQueen KA, Dennis CL, Stremler R, Norman CD. A pilot randomized controlled trial of a breastfeeding selfefficacy intervention with primiparous mothers. Journal of obstetric, gynecologic\&neonatal nursing. $2011 ; 40^{13}: 35-46$.

3. Backstrom CA, Wahn EIH, Ekstrom AC. Two side of breastfeeding support: experiences of women and midwives. International breastfeeding journal. 2010;29 nov:5.

4. Badan Penelitian dan Pengembangan Kesehatan Kementerian Kesehatan Republik Indonesia. Riset kesehatan dasar 2010. Jakarta: Kemenkes RI; 2010

5. Dinas Kesehatan Kota Balikpapan. Profil kesehatan 2012.

6. Roesli U. Panduan praktis menyusui. Sentra laktasi Indonesia. Jakarta: Puspaswara; 2008.

7. Glanz K, Rimer BK, Viswanath K. Health behaviour and health education: Theory, research, and practice. 4 ed. San Francisco: Jossey-Bass; 2008.

8. Awano M, Shimada K. Development and evaluation of a self care program on breastfeeding in Japan: a quasiexperimental study. International breastfeeding journal. 2010;5:9 